\title{
Criteria for Assessing the Energy-Ecological Effectiveness of using the Sludge of Waste Treatment Plants as Components of Liquid Composite Fuels
}

\author{
By Iryna Suvorova ${ }^{1}$, Oleh Kravchenko ${ }^{1}$, Vitalii Goman ${ }^{1}$, Ihor Baranov ${ }^{1}$
}

\begin{abstract}
The challenging issues in the sustainable development of a state currently are the problems of protecting the environment from contamination, increasing the capacity of systems for recycling and reusing water, and the development of resource saving and non-waste technologies. The authors have developed and introduced the technology of hydrocavitation activation of liquid hydrocarbons to create composite fuels that can contain off-spec hydrocarbons, including stale fuel oil, oil tanker outwashes, stillage bottoms, coal, bio mass, industrial wastes and the sludge of wastewater treatment plants. The main criteria were defined for assessing the energy-ecological effectiveness of using sludge in municipal wastewater as a component of composite fuels. The criteria are as follows: the calorific capacity of the fuel mixture, the energy effectiveness of its use as an energy resource, consumer properties, and the environmental performance of combusting this kind of fuel. Using these criteria during the production and combustion of composite fuels obtained with hydrocavitation activation allows producing high-quality fuel mixtures with specified thermophysical and consumer properties. This opens the prospects of more effective usage of hydrocarbon resources and of solving simultaneously two problems: the production of surplus energy and environmental load reduction during the disposal and neutralisation of moisture-containing waste.
\end{abstract}

Keywords: sludge; bydrocarbon resources; bydrocavitation activation; composite fuels; waste disposal and neutralisation

\section{Introduction}

Due to big concentrations of xenobiotics and their high resistance to decomposition, self-purification of nature proceeds very slowly. Therefore, a pressing ecological task is environment rehabilitation: effective treatment of industrial and agricultural waste; detoxifying and restoring the fertility of land contaminated with toxic chemicals; disposal of sewage sludge in wastewater treatment plants; cleaning water sources, etc.

One of the many environmental challenges of modern civilisation is the disposal of industrial and domestic waste, including the waste of municipal sewage treatment plants. Human household and industrial production activities produce liquid waste in the form of sewage, which is typically discharged into the sewerage system. Sludge is formed when wastewater passes through the purification stages at sewage treatment plants. In the majority of cases, it resists any treatment apart from being dewatered in sludge pits in natural conditions. This process is protracted and needs huge areas for sludge detention 
ponds. Besides, sludge storage creates an unfavourable gas-and-air environment and contaminates soil and ground water with toxic components in the sludge composition. The sludge in municipal wastewater treatment plants comprises organic (up to 80\%) and mineral (about 20\%) agents extracted from the water by mechanical, biological and physico-chemical treatment [1]. They include substances that have generally toxic, toxicogenic, embryotoxic, carcinogenic and other adverse properties. They can contain heavy metals, pathogenic organisms, an excess amount of nitrates, toxic substances, pesticides, polychlorous biphenyls, aliphatic compounds, ethers, mono- and polycyclic aromatic substances, phenols, and nitrosamines. The noxious gases liberated by the wastewater sludge have a sharp offensive odour and can exceed the maximum admissible concentration by several-fold. The widespread methods of treatment of sludge in methane tanks or their disposal to sludge detention ponds are inadequate, not efficient and require the alienation of big land areas close to contamination sources [2]. In the majority of cases, the sludge storage sites are filled to overflowing and are unanble to handle the continuous sludge inflow. In addition, sludge pits are a threat to the environment owing to the high content therein of harmful viruses, bacteria, toxic gases, and harmful chemical compounds. Besides, digestion in natural conditions yields offensive odours that are a source of vast discomfort for the public. Owing to the presence of high concentrations of phosphorous and nitrogen, wastewater sludge is a good fertiliser. However, at the same time, it can be a contamination source because, apart from containing organic substances, it can contain big amounts of heavy metals. This is one of the reasons why the sludge incineration technology is recently becoming more common. This technology also yields a positive energy balance and provides for an efficient usage of the calorific capacity of the sludge [3].

Sludge drying, followed by its incineration, is widespread only in Germany, and to a lesser extent in Poland and Sweden. However, this method of sludge disposal requires huge capital investment and consumption of expensive hydrocarbons for organising drying and combustion of such waste by incineration [4, 5]. It also requires significant electric power consumption for disposal of such waste using plasma methods.

\section{Producing Composite Fuels by Using Hydrocavitation Activation}

Ukraine is facing the pressing problem of searching for alternative energy sources. One such source can be the excess sludge of municipal wastewater treatment plants.

IPMash NAS of Ukraine has developed the scientific and practical basics of using hydrocavitation activation of liquid hydrocarbons to produce composite fuels. They can be composed of off-spec hydrocarbons, including stale fuel oil, oil tanker outwashes, stillage bottoms, coal, bio mass, industrial wastes, etc. [6 - 11]. Such an approach helps using hydrocarbon resources more efficiently and it solves two problems simultaneously - production of surplus energy and disposal and neutralisation of waste.

Research in the processes of producing and combusting composite fuels was conducted based on using oil refining stillage bottoms and sludge of wastewater treatment plants and the energy-technological research complex developed and built at IPMash NAS of Ukraine. Its schematic diagram is shown in Fig. 1. 


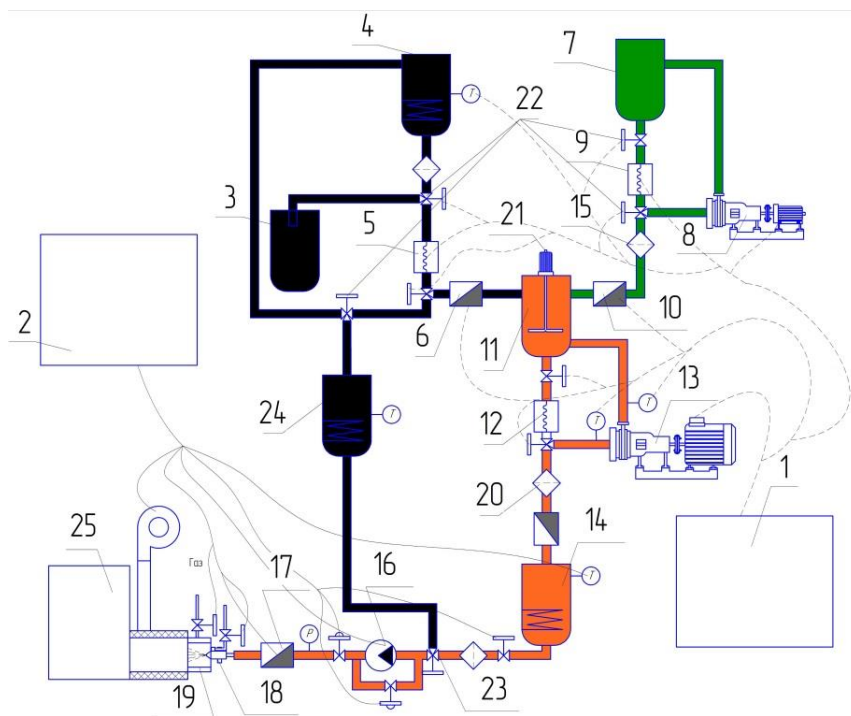

1. ACLF production cotrol panel

2. Fuel combustion control panel

3. Tank holding a hydrocarbon

4. Hydrocarbon heater

5. Hydrocarbon transfer pump

6. Strain-gauge sensor unit

7. Tank with liquid waste

8. Dismembrator

9. Waste transfer pump

10. Weigher

11. ACLF production tank

12. ACLF transfer pump

13. Hydrocavitation device

14. Finished ACLF stock tank

15. Liquid waste filter

16. Pump for feeding fuel for combustion

17. Flow rate meter

18. Hydrovortex nozzle

19. Burner

20. ACLF filtration system

21. Screw mixer

22. Servo-operated cock

23. Three-way servo-operated valve

24. Tank for hydrocarbons

25. Steam boiler

Figure 1 - Schematic diagram of the energy-technological complex for research in the processes of production, preparation and combustion of composite fuel

The key components of the complex (Fig. 1) for implementing hydrocavitation activation during the production and combustion of composite fuel are hydrocavitation device 13 for producing the fuel mixture, as well as hydrovortex nozzle 18 and burner 19 for atomising and combusting the mixture. Standard commercially available devices and units are used as other components of the complex.

During experimental research, stillage bottoms of straight-run oil refining are used as hydrocarbon resources for the composite fuel. Their physico-chemical characteristics are given in Table 1. Sludge from wastewater treatment plants was used as the watercontaining fuel component. The physico-chemical characteristics of the sludge are given in Table 2.

Table 1 - Physico-chemical characteristics of straight-run oil refining stillage bottoms

\begin{tabular}{|l|c|c|c|c|c|}
\hline $\begin{array}{l}\text { Kind of } \\
\text { hydrocarbon }\end{array}$ & $\begin{array}{c}\text { Moisture } \\
\text { content, } \%\end{array}$ & $\begin{array}{c}\text { Ash } \\
\text { content, } \%\end{array}$ & $\begin{array}{c}\text { Sulphur } \\
\text { content, } \%\end{array}$ & $\begin{array}{c}\text { Calorific } \\
\text { value, } \mathrm{MJ} / \mathrm{kg}\end{array}$ & $\begin{array}{c}\text { Viscosity, } \\
\mathrm{MPa} \cdot \mathrm{s}\end{array}$ \\
\hline Stillage bottoms & 0.11 & 0.09 & 0.84 & 44.0 & 26 \\
\hline
\end{tabular}

Table 2 - Physico-chemical characteristics of sludge from wastewater treatment plants

\begin{tabular}{|l|c|}
\hline Component & Mass share, \% \\
\hline Free moisture & 94.0 \\
\hline Bound moisture & 0.67 \\
\hline Organic substances & 2.47 \\
\hline Ash (inorganic residue) & 2.86 \\
\hline
\end{tabular}

While producing the composite fuel, the operational effectiveness of cavitation equipment operational conditions was assessed by investigating the dependence of the 
calorific capacity of artificial composite liquid fuel (ACLF) on the hydrocavitation activation process conditions. The basic parameters that determine the fuel treatment operating conditions in the hydrocavitation device are rotor rotational speed and treatment time. Depending on the rotor rotational speed, the treatment time varies (the greater the rotational speed, the shorter the treatment time). The mixture was subjected to treatment up to $\mathrm{t}=98{ }^{\circ} \mathrm{C}$. Twenty-two operating conditions were investigated, with the circumferential speed of the impactors of working members being set to within 30 to $75 \mathrm{~m} / \mathrm{s}$.

Experimental data processing enabled building a regression mathematical model of the dependence of the calorific capacity of the composite fuel on the rotational speed of the hydrocavitation equipment working members at the 1:1 mass ratio of fuel components.

$$
f(x)=-1.8865 \cdot 10^{-8} x^{6}+6.2315 \cdot 10^{-6} x^{5}-8.4139 \cdot 10^{-4} x^{4}+5.9233 \cdot 10^{-2} x^{3}-
$$

$-2.2856 \cdot 10^{0} x^{2}+4.5817 \cdot 10^{1} x^{5}-3.5044 \cdot 10^{2}$

Fig. 2 shows the dependence of the calorific capacity of the composite fuel on the rotational speed of the impactors of the hydrocavitation device (HCD) working members. The graph of the constructed mathematical model is monotonous, though essentially nonlinear: at $30-40 \mathrm{~m} / \mathrm{s}$, a slight increase in the fuel calorific value was observed; at $40-65 \mathrm{~m} / \mathrm{s}$, the fuel calorific value increase was significant and close to linear; beyond $65 \mathrm{~m} / \mathrm{s}$ the fuel calorific value virtually does not increase.

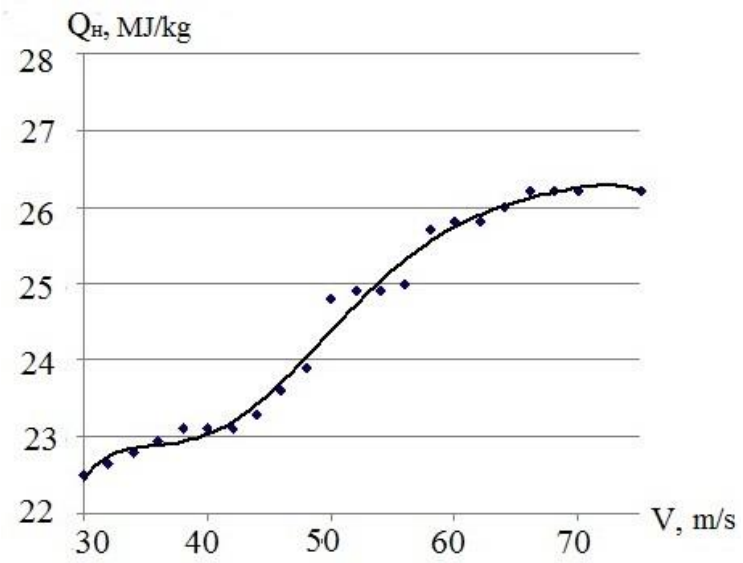

Figure 2 - Calorific value of composite fuel vs. circumferential speed of impactors of bydrocavitation device working members

An increase in the calorific value of composite fuel, as compared to the previously emulsified fuel mixture, can be attributed to that, with increasing hydrocavitation impact, physico-chemical processes are intensified in the emulsion of the "hydrogen-water" type, such as hydrolysis, hydrogenation, and hydrocracking, during which new oxygencontaining hydrocarbon compounds are formed (Fig. 3). This is confirmed by spectral investigations of the composition of the produced ACLF with the SpectrumOne spectrograph. During spectral analysis, potassium bromide was used for combustion of the sample of the fuel mixture being investigated. 

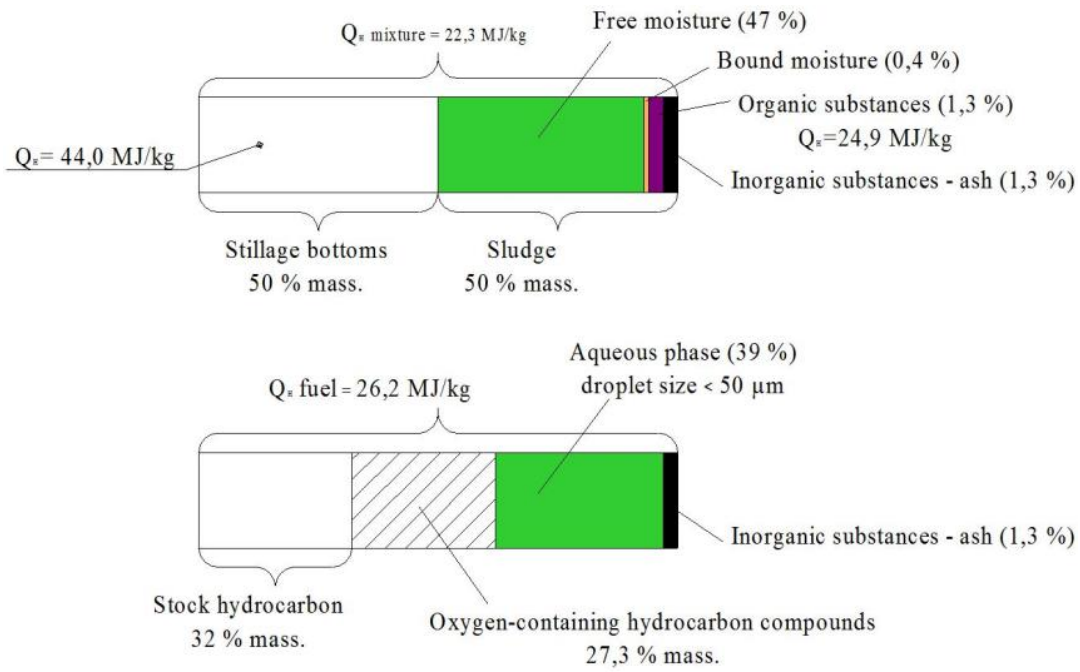

Figure 3 - Scheme for producing new bydrocarbon compounds after preliminary emulsification and bydrocavitation activation of composite fuel

During hydrocavitation activation of the fuel mixture, bound moisture and organic substances are included in the composition of produced hydrocarbon compounds. Using the dependence of the varying calorific value of the composite fuel on the circumferential speed of the impactors of HCD working members enables determining effective hydrocavitation equipment operating conditions during the production and combustion of the given kind of energy resource [12, 13]. Follow-up experimental research was conducted with HCD operating at the circumferential speed of $70 \mathrm{~m} / \mathrm{s}$ of the impactors of working members.

\section{Impact of the Content of Sludge in the Composite Fuel on the Calorific Value}

During the production of multiphase composite fuels by using hydrocavitation activation, the intensification of physico-chemical processes such as hydrolysis, hydrogenation and hydrocracking facilitates the production of new fuel components. As a result, the calorific value of the produced energy resource can change. Investigation of the increasing calorific value of the composite fuel produced using hydrocavitation activation (HCA), as compared to the calorific heat of hydrogen in the fuel mixture, is based on the criterion [14]

$\mathrm{K}_{\mathrm{sh}}=100-\frac{Q_{\mathrm{M}}}{Q_{c f}} \cdot \mathrm{M}_{\mathrm{M}}$,

where

$\mathrm{Q}_{\mathrm{M}}$ is calorific capacity of stock hydrocarbon in the composition of the produced composite fuel, $\mathrm{MJ} / \mathrm{kg}$;

$\mathrm{Q}_{\mathrm{cf}}$ is calorific capacity of composite fuel, $\mathrm{MJ} / \mathrm{kg}$;

$\mathrm{M}_{\mathrm{M}}$ is percentage mass content of stock hydrocarbon in the composite fuel, $\%$.

For example, in the case of composite fuel with a $70 \%$ mass content of hydrocarbon and a $30 \%$ mass content of the aqueous phase, if $\mathrm{Q}_{\mathrm{M}}=42 \mathrm{MJ} / \mathrm{kg}$ and $\mathrm{Q}_{\mathrm{cf}}=36 \mathrm{MJ} / \mathrm{kg}$, 
then $K_{\text {sh }}=100-\frac{42}{36} \cdot 70=18.33 \%$.

This criterion helps determine the percentage increase of the calorific value of composite fuel when it is produced using HCA, as compared to the theoretical calorific value that can be calculated by adding up the calorific value of all combustible components according to their mass content in the fuel mixture. Besides, calculation results by this criterion help obtain a tentative assessment of the possibility of increasing the thermal energy produced when using this kind of energy resource.

With the suggested method, simultaneously with calorimetry investigations, it is possible to find the energy effectiveness of the used fuel by measuring the heat generation capacity of fuel-consuming equipment, in particular, determine the parameters of generated steam or heated water during the combustion of fuel resources in steam or water-heating boilers. Such determination can demonstrate not only the amount of produced thermal energy when using this kind of fuel, but it can also determine the effectiveness of the combustion process in case of a significant difference between theoretical and experimental energy parameters.

The energy effectiveness of using composite fuel as an energy resource for a steam boiler is computed by the criterion [14]

$\mathrm{K}_{\mathrm{ee}}=100-\frac{b_{\mathrm{T}}}{b_{\mathrm{M}}} \mathrm{M}_{\mathrm{M}}$,

where

$b_{\mathrm{T}}$ is specific composite fuel consumption per $1 \mathrm{t}$ of steam, $\mathrm{kg} / \mathrm{t}$;

$b_{\mathrm{M}}$ is specific consumption of stock hydrocarbon per $1 \mathrm{t}$ of steam, $\mathrm{kg} / \mathrm{t}$;

$\mathrm{M}_{M}$ is percentage mass content of stock hydrocarbon in the composite fuel (\%).

For instance, in the case of composite fuel with a $70 \%$ content of hydrocarbon and a 30 $\%$ content of an aqueous phase, if $b_{\mathrm{M}}=80 \mathrm{~kg} / \mathrm{t}$ of steam and $b_{\mathrm{T}}=106 \mathrm{~kg} / \mathrm{t}$ of steam, then $\mathrm{K}_{\mathrm{ee}}=100-\frac{106}{80} \cdot 70=7.25 \%$.

To determine the impact of the sludge content in the composite fuel, the fuel mixture was created with various component ratios. The physico-chemical characteristics of composite fuels are shown in Table 3. According to Table 3, the increase in the calorific value of composite fuel in reference to the calorific capacity of the consumed amount of stock hydrocarbon by criterion (2) was $16 \%$ depending on the component ratios. Note that the kinematic viscosity of produced composite fuels is significantly higher than that of the stock hydrocarbon. This is due to the formation of an adsorption-solvent layer on the phase interface of the droplet of the water-fuel suspension.

Table 3 - Physico-chemical characteristics of composite fuels

\begin{tabular}{|l|c|c|c|c|c|}
\hline & $\begin{array}{c}\text { Moisture } \\
\text { content, \% }\end{array}$ & $\begin{array}{c}\text { Ash } \\
\text { content, \% }\end{array}$ & $\begin{array}{c}\text { Calorific } \\
\text { value, } \mathrm{MJ} / \mathrm{kg}\end{array}$ & $\begin{array}{c}\text { Dynamic } \\
\text { viscosity, } \mathrm{MPa} \cdot \mathrm{s}\end{array}$ & $\begin{array}{c}\mathrm{K}_{\text {sh }}, \\
\%\end{array}$ \\
\hline Stillage bottoms & 0.58 & 0.08 & 44.0 & 26 & - \\
\hline CF (30 \% sludge) & 22.12 & 0.88 & 31.8 & 318 & 3.15 \\
\hline CF (35 \% sludge) & 29.80 & 1.11 & 30.5 & 427 & 6.23 \\
\hline CF (40 \% sludge) & 31.21 & 1.44 & 29.4 & 519 & 10.20 \\
\hline CF (45\% sludge) & 37.76 & 1.47 & 27.8 & 612 & 12.95 \\
\hline CF (50\% sludge) & 40.46 & 1.86 & 26.2 & 639 & 16.03 \\
\hline
\end{tabular}


When using hydrocavitation activation, the produced composite fuels are very homogeneous. Fuel mixture homogeneity is required to ensure the necessary stability of the produced ACLF and combustion neutralisation of noxious substances in the industrial waste added to the composite fuel, and to maintain a quality combustion process of the given kind of energy resource.

\section{Combustion of Artificial Composite Liquid Fuel (ACLF)}

Experimental research in the processes of ACLF combustion have demonstrated the unfeasibility of using standard burners installed in steam boilers because the presence of high viscosity and solid inclusions leads to contamination of burner assemblies, loss of flame and termination of energy installation operation. Therefore, industrial research is conducted using hydrovortex nozzles [12, 13, 15 - 17] and a burner developed by IPMash NAS of Ukraine. These devices ensure ultrafine spraying and quality combustion of produced high-viscosity composite fuels with a solid phase. Table 4 summarises the results of heat engineering research in combustion of composite fuel.

Analysis of heat engineering research in the process of combustion [14] has shown that, when composite fuel is used as an energy resource, hydrocarbon stock saving can reach $10 \%$.

Table 5 shows a comparison of gas analysis results with effective environmental norms [18] for maximum admissible concentrations (MAC) of noxious substances during combustion of investigated fuels.

Table 4-Results of heat engineering research in combustion of composite fuel

\begin{tabular}{|l|c|c|c|c|c|}
\hline Fuel & $\begin{array}{c}\text { T gas, } \\
{ }^{0} \mathrm{C}\end{array}$ & $\begin{array}{c}\text { P steam, } \\
\mathrm{MPa}\end{array}$ & $\begin{array}{c}\text { Boiler } \\
\text { efficiency, \% }\end{array}$ & $\begin{array}{c}\text { Fuel consumption } \\
\text { per 1 of steam, kg }\end{array}$ & $\mathrm{K}_{\text {ee, } \%}$ \\
\hline Stillage bottoms & 302.4 & 0.4 & 81.8 & 80 & - \\
\hline CF (30\% sludge) & 293.2 & 0.4 & 83.2 & 108 & 5.5 \\
\hline CF (35\% sludge) & 291.8 & 0.4 & 84.6 & 115 & 6.6 \\
\hline CF (40\% sludge) & 291.4 & 0.4 & 85.0 & 124 & 7.0 \\
\hline CF (45\% sludge) & 289.5 & 0.4 & 85.8 & 133 & 8.6 \\
\hline CF (50\% sludge) & 286.6 & 0.4 & 86.0 & 145 & 9.4 \\
\hline
\end{tabular}

Table 5 - Results of gas analysis of flue gases during combustion of investigated composite fuels and stock hydrocarbons

\begin{tabular}{|l|c|c|c|c|c|c|c|}
\hline Fuel & $\alpha$ & $\mathrm{CO}, \mathrm{ppm}$ & $\begin{array}{c}\mathrm{CO}_{2}, \\
\%\end{array}$ & $\begin{array}{c}\mathrm{O}_{2}, \\
\%\end{array}$ & $\begin{array}{c}\mathrm{NO}, \\
\mathrm{ppm}\end{array}$ & $\begin{array}{c}\mathrm{NO}_{\mathrm{x}}, \\
\mathrm{ppm}\end{array}$ & $\begin{array}{c}\mathrm{SO}_{2}, \\
\mathrm{ppm}\end{array}$ \\
\hline Stillage bottoms & 1.31 & 12 & 11.2 & 4.2 & 119 & 119 & 177 \\
\hline Composite fuel (30 \% sludge) & 1.36 & 20 & 10.8 & 4.7 & 123 & 123 & 171 \\
\hline Composite fuel (35\% sludge) & 1.42 & 32 & 10.5 & 5.1 & 121 & 121 & 155 \\
\hline Composite fuel (40 \% sludge) & 1.43 & 41 & 9.8 & 5.8 & 114 & 114 & 168 \\
\hline Composite fuel (45\% sludge) & 1.45 & 28 & 10.4 & 5.2 & 126 & 126 & 149 \\
\hline Composite fuel (50 \% sludge) & 1.47 & 52 & 9.6 & 6.4 & 134 & 134 & 156 \\
\hline MAC norm [89] & - & 250 & - & - & 500 & 500 & 250 \\
\hline
\end{tabular}


According to the data in Table 5, using composite fuel with addition of sludge from wastewater treatment plants as an energy resource meets current environmental control requirements. Hence, using this kind of fuel as an energy resource solves not only the energy problem of generating less costly heat energy or electric power, but also the environmental problem of disposal of industrial waste to reduce the environmental load.

\section{Conclusions}

The authors have demonstrated that the technological parameters of the process of producing composite fuels by using the hydrocavitation activation technology have an essential impact not only on the thermal physical properties of the produced fuel composition, but also on the energy environmental characteristics of its combustion.

The key criteria were determined to assess the energy environmental effectiveness of using the sludge from municipal wastewater as a composite fuel component. The effectiveness characteristics are as follows: the calorific value of the fuel mixture; the energy effectiveness of its usage as an energy resource; the consumer properties and the environmental parameters of combustion of this kind of fuel.

The dependence of an increasing calorific value of composite fuel on the characteristics of hydrocavitation activation during fuel production was established. This enables determining the requisite operating conditions of operation of hydrocavitation equipment during the production of this kind of energy resource. An experimental achievement was the increase in the calorific value of the composite fuel based on oil refining stillage bottoms with addition of sludge from municipal wastewater treatment plants.

Experiments demonstrated that using HCA in the process of spraying the produced fuel emulsion ensures the following: quality mixture formation with an oxidiser, an increase in composite fuel combustion efficiency and virtually complete combustion disposal of hazardous components of moisture-containing waste. According to research in the processes of combustion of the produced composite fuel, the composition of flue gases is in full accord with current environmental requirements to power engineering equipment.

\section{References}

Blagorazumova A. Treatment and dewatering of sludge in municipal wastewater, 2nd ed., revised and supplemented, Lan Publishers, SPb., 2014. 208 p.

Pakhnenko Ye. Wastewater sludge and other nonconventional organic fertilisers, BINOM: Laboratory of knowledge, Moscow, 2007. 311 p.

Treatment of sewage sludge [Electronic resource] URL: http://www.green-pik.ru/sections/96.html \&article=17.

Nasyrov I. Problems in disposal of sludge from wastewater treatment plants / Nasyrov I., Mavrin G., and Shaikhiev I. // Bull. Technological University, Kazan, 2015. v. 18, No. 19. p. 257-259.

Liuft Ya. Treatment of sewage sludge: rewarding experience and practical advice / Liuft Ya , Oyiaila T., Ruokanen L., Zinchuk O. // Project for urban reduction of eutrophication of the Environmental Commission of the Union of Baltic Cities. Finland, 2012. 125 p. 
Kravchenko O. Leading-edge technologies of producing and combusting composite fuels based on activation methods / Kravchenko O., Suvorova I., Baranov I., Goman V. // Municipal economy of cities. Ser. Energy-effective equipment and technologies in the housing and utilities sector. Kharkiv: O.M. Beketov Kharkiv National University. 2014. Issue 118 (1). p. 29 - 33.

Kravchenko O. Nonconventional energy technologies for effective production and use of artificial composite liquid fuels / Kravchenko O., Suvorova I., Smirnov Ya., Kholobtsev S. // Aerospace equipment and technology. 2006. Issue No. 10(36). p. 91-97.

Kravchenko O. Nonconventional methods of producing and combusting liquid fuels / Kravchenko O., Suvorova I., Kholobtsev S. // Bull. Int. Slavic University. 2007. v 10, No. 1. p.14-19.

Kravchenko O. New hydrocavitation technologies in the processes of effective production and usage of hydrocarbon-containing energy carriers. Bull. National Technical University "Kharkiv Polytechnic Institute". Kharkiv: NTU KhPI, 2007. No. 2. p. 171-178.

Kravchenko O. Nonconventional methods of producing artificial composite liquid fuels/ Kravchenko O., Suvorova I., Kholobtsev S. // Bull. SevGTU. Ser. Mechanics, power engineering, ecology. Sevastopol: SevNTU, 2008. Issue 87. p. 34-38.

Patent 79617, Ukraine, IPC (2006) C10G 15/00. Method of cavitation hydrogenation and hydrolysis of hydrocarbons and device for implementation thereof / Miroshnichenko I., Matsevity Yu., Miroshnichenko I., Kravchenko O., Tarelin A.; applicant and patent holder A.M. Pidhornyi Institute for Mechanical Engineering Problems of NAS of Ukraine. - No. a 2005 00188; filed 10.01.2005; publ. 10.07.07, Bull. No. 10.

Kravchenko O. Hydrocavitation activation in the technologies of production and combustion of composite fuels/ O. Kravchenko, I. Suvorova, I. Baranov, V. Goman // Eastern-European Journal of Enterprise Technologies. 2017. 4 /5 (88). P. 33-42.

Suvorova I. Innovative Technologies for Utilization and Disinfection of Waste to Ensure Sustainable Development of Civilization / I. Suvorova, O. Kravchenko, I. Baranov, V. Goman // European Journal of Sustainable Development. Rome, 2018. Vol. 7, No. 4. P. 423-434.

Goman V. Increasing the effectiveness of the processes of producing and combusting composite fuel using hydrocavitation activation. Author's Abstract of PhD (Eng.) Dissertation in the specialty 05.14.06 - Engineering heat physics and industrial heat engineering. - A.M. Pidhornyi Institute for Mechanical Engineering Problems of NAS of Ukraine, Kharkiv, 2019. Technological Centre Printing House. Certificate on filing a publishing subject DK No. 4452 of 10.12.2012 Address: 4 Shatilova Dacha St, Kharkiv 61145. 26 pp.

Utility patent No. 18922, Ukraine, IPC7 B01F 3/08, B 63 B59/00/ Mixer burner / I. Suvorova, O. Kravchenko; No. U200606857; filed 19.06.2006; publ. 15.11.06, Bull. No.11.

Utility patent No. 89291, Ukraine, IPC (2014.01) F23D 11/00, B01F 3/00, B01F 5/00. Activator nozzle / O. Kravchenko, I. Suvorova, I. Baranov, L. Tarasenko; applicant and patent holder A.M. Pidhornyi Institute for Mechanical Engineering Problems of NAS of Ukraine. - No. u 2013 14346; filed 09.12.2013; publ. 10.04.2014, Bull. No. 7.

Patent 113894 (Ukraine), IPC B01F /16. Hydrocavitation device for treatment of liquid / Kravchenko O., Goman V., Simbirskyi O., Momot V.; applicant and patent holder A.M. Pidhornyi Institute for Mechanical Engineering Problems of NAS of Ukraine. No. a 2015004466; filed 07.05.2015; publ. 27.03.2017, Bull. No. 6. 4 pp.

On the approval of the norms of maximum admissible discharge of contaminants from stationary sources: Order of the Ministry of Environmental Control of Ukraine of 27 June 2006 No. 309 / Ministry of Environmental Control of Ukraine. URL:https://zakon4.rada.gov.ua/laws/show/z0912-06 (accessed on 18.04.2017). 